\title{
THE FEATURES THE AUTOTROPHIC AND HETEROTROPHIC NITRIFICATION IN THE ROOT ZONE OF WINTER RYE PLANTS UNDER THE USE OF MINERAL FERTILIZERS AND DIAZOBAKTERYN
}

\author{
I. G. Korotka, V. V. Volkogon \\ Institute of Agricultural Microbiology and Agroindustrial Manufacture, UAAS \\ 97, Shevchenka str., Chernihiv, 14027, Ukraine; e-mail: chychvaga_i@i.ua
}

The paper depicts the study of mineral nitrogen and pre-sowing seeds bacteryzation on the development of nitrogen fixing bacteria and the activity of autotrophic and heterotrophic nitrification. It was revealed that nitrification activity in the root zone of winter rye plants rises together with the increase of mineral nitrogen doses. Heterotrophic nitrification plays a significant role in the formation of nitrate pool in the root zone, especially during the early stages of plants organogenesis. Application of the microbial preparation Diazobakteryn had enhanced the activity autotrophic and heterotrophic nitrification processes in the rhizosphere soil of plants in the spring, during the early stages of their development while during the next organogenesis phases the reduction of nitrification processes was observed. In plants-free soil the contribution of heterotrophic nitrification to biological transformation of nitrogen was negligible.

Key words: autotrophic nitrification, heterotrophic nitrification, Diazobakteryn, winter rye, inoculation, fertilizers.

Microbiological transformation of nitrogen compounds to nitrates plays an important role in the nitrogen cycle: on the one hand it increases the denitrification activity (by increasing the concentration of nitrates in the soil), on the other - limits the activity of nitrogen fixation and microbial immobilization of nitrogen [1]. Nitrification is most active if the sufficient amount of ammonia nitrogen is present under the soil $\mathrm{pH}$ close to neutral and sufficient aeration. Since these conditions are also favorable for plants growth and development, the nitrification rate in soils is often used for diagnostic purposes [2].

Peculiarities of autotrophic and heterotrophic nitrification depend upon the type of biogeocenosis [3]. In soils of natural ecosystems (e. g., forest cenosis) heterotrophic nitrification is dominant, which mainly occurred due to the fungal activity $[4 ; 5]$. In agrocenosis of cultivated soils for contrast, the share of autotrophic nitrifying microorganisms account for almost 84-99 \% of ammonium oxidation [3], as the soil cultivation creates favorable conditions for the operation nitrification autotrophic bacteria: no climax plant groups are present, crop rotation, enhanced mineralization of nitrogen compounds, increased soil aeration; use of manure, and ammonium fertilizers, served as an energy substrate for nitrifying autotrophic bacteria. At the same time, the reduction of fungi population, many of which are capable of heterotrophic nitrification, was observed in the arable soils. All this leads to almost complete transfer of leading position to nitrifying autotrophic bacteria.

Kurakov A. V. with his colleagues [6] have found that in laboratory conditions heterotrophic microorganisms contribute to the formation of nitrates in virgin soils in average of $70 \%$, while the share of nitrifying autotrophic bacteria is only $30 \%$. In cultivated soils, $73-92 \%$ of nitrates are formed by autotrophic nitrifying bacteria.

Among the issues related to the nitrification processes, the behavior of rhizosphere microorganisms towards the ammonium oxidation remains unexplored. Theoretically, within given ecological niche heterotrophs should prevail, due to the presence of carbon in root exudates, but plants can also influence the nitrate assimilation. Investigation of ammonium oxidation pe- 
culiarities in the root zone of plants under the inoculation and application of mineral fertilizers can be used as the grounds for optimization nitrogen fertilization of agricultural crops.

Materials and methods. The nitrification process orientation in the root zone of winter rye plants was investigated under the different agricultural backgrounds and pre-sowing seed inoculation with microbial preparation Diazobacteryn (agent Azospirillum brasilense 18-2) (TU 24.1-00497360-002:2005) in a small plots field experiments on sod-podzolic silty-sandy cultivated soil on experimental field of the Institute of Agricultural Microbiology and Agroindustrial Manufacture NAAS $\left(\mathrm{pH}_{\text {sol }}-6.2\right.$, humus content - $1.2 \%$, nitrogen content easily hydrolyzed (by Kornfield) — $54.9 \mathrm{mg} / \mathrm{kg}$, $\mathrm{P}_{2} \mathrm{O}_{5}-330 \mathrm{mg} / \mathrm{kg}, \mathrm{K}_{2} \mathrm{O}-148 \mathrm{mg} / \mathrm{kg}$ ). Close to neutral soil $\mathrm{pH}$ is caused by the soil cultivation and liming.

Experimental design:

\section{Without bacterization}

1. Without fertilizers (control)

2. $\mathrm{N}_{30} \mathrm{~K}_{20} \quad\left(N_{10}\right.$ in fall $+N_{20}$ early spring)

3. $\mathrm{N}_{60} \mathrm{~K}_{40} \quad\left(N_{30}\right.$ in fall $+N_{30}$ early spring)

4. $\mathrm{N}_{90} \mathrm{~K}_{60}$ ( $N_{30}$ in fall $+N_{30}$ early spring + $+N_{30}$ at stem elongation stage)

5. $\mathrm{N}_{120} \mathrm{~K}_{80}\left(N_{30}\right.$ in fall $+N_{45}$ early spring + $+N_{45}$ at stem elongation stage)

II. Diazobacteryn bacterization

6. Without fertilizers

7. $\mathrm{N}_{30} \mathrm{~K}_{20}$ ( $N_{10}$ in fall $+N_{20}$ early spring)

8. $\mathrm{N}_{60} \mathrm{~K}_{40} \quad\left(N_{30}\right.$ in fall $+N_{30}$ early spring)

9. $\mathrm{N}_{90} \mathrm{~K}_{60} \quad\left(N_{30}\right.$ in fall $+N_{30}$ early spring + $+N_{30}$ at stem elongation stage)

10. $\mathrm{N}_{120} \mathrm{~K}_{80}\left(N_{30}\right.$ in fall $+N_{45}$ early spring + $+N_{45}$ at stem elongation stage)

Calculation of NPK rates was performed taking into the account the nutritional contents in the soil and its removal with the planned yield of $3.5 \mathrm{t} / \mathrm{ha}$. The size of experimental plots was 9 sq. m. In order to exclude the plants role in the nitrification processes the fallow plots $(1 \mathrm{~m} \times 1 \mathrm{~m})$ were used.

The number of autotrophic nitrifying bacteria of phase I was determined by gradual dilution in Vinogradsky liquid medium. The number of autotrophic nitrifying bacteria of phase II on the Watson-Waterbern culture medium [7]. The number of cells per volume unit was calculated using McCready table based on variation statistics methods.
Composting method by D. Zvyagintsev [8] was used to study the nitrification process and evaluation of the contribution of autotrophic and heterotrophic nitrifying microorganisms in the nitrate formation. To determine the potential nitrifying activity some bottles were not only watered but have received the ammonium sulfate (100 mg N-NH $/$ g soil) and thoroughly mixed. In order to isolate the heterotrophic component in nitrate accumulation, the course of autotrophic nitrification was inhibited with 4-amino1,2,4-triazole (100 mg / g soil). Nitrate contents was determined using ion-selective electrodes [9]. The three-fold experimental replication was used.

Results and discussion. Under the favorable conditions large portion of nitrogen fertilizers are subject to nitrification. According to A. I. Nesterova [10] in well aerated slightly acid soils with high biological activity more than half of the introduced ammonium is nitrified in 15 days. The studies of the influence of mineral nitrogen and seeds inoculation with Diazobacteryn on the number of nitrifying autotrophic bacteria in rhizosphere soil of winter rye plants have revealed that the introduction of nitrogen fertilizers had contributed to the increase of autotrophic nitrifying bacteria. Seeds inoculation with Diazobacteryn had no clear patterns regarding the influence of biological preparation on the development of nitrifying bacteria in 2011 (Table 1). However, the studies performed in 2012 and 2013 have indicated its positive impact on the development of nitrifying bacteria (Tables 2-3).

Thus, Diazobacteryn use can provide a comfortable environment for plants growth and development by contributing to the increase of the number nitrifying bacteria and their activity due to their better nutrition supply with nitrates.

Inhibitory approach in determining the nitrification activity can provide a differentiated evaluation of auto- and heterotrophic nitrifying microorganisms' part in oxidative link of nitrogen cycle.

Determination of the total nitrification activity in 2013 had showed an process activity increase according to the introduced doses of nitrogen fertilizers. The highest nitrification activity was observed at the beginning of the growing season (Fig. 1), with the subsequent reduction during the plant ontogenesis (Fig. 2-3).

The studies performed have indicated that 
Table 1. Influence of seeds inoculation and mineral fertilizers on the development of nitrifying bacteria in rhizosphere soil of winter rye plants, 2011

\begin{tabular}{|c|c|c|c|c|c|c|}
\hline \multirow{3}{*}{ Variants } & \multicolumn{6}{|c|}{ Number of bacteria, tsnd. in $1 \mathrm{~g}$ dry soil } \\
\hline & \multicolumn{3}{|c|}{$\begin{array}{l}\text { Autotrophic nitrifying bacteria } \\
\text { of I phase }\end{array}$} & \multicolumn{3}{|c|}{$\begin{array}{l}\text { Autotrophic nitrifying bacteria } \\
\text { of II phase }\end{array}$} \\
\hline & $\begin{array}{c}\text { Stem } \\
\text { elongation }\end{array}$ & Flowering & Milk stage & $\begin{array}{c}\text { Stem } \\
\text { elongation }\end{array}$ & Flowering & Milk stage \\
\hline \multicolumn{7}{|c|}{ Without inoculation } \\
\hline $\begin{array}{l}\text { Without fertili- } \\
\text { zers, control }\end{array}$ & 0,5 & 1,0 & 0,5 & 0,3 & 0,3 & 0,3 \\
\hline $\mathrm{N}_{30} \mathrm{~K}_{20}$ & 2,6 & 1,0 & 0,3 & 0,3 & 0,3 & 0,5 \\
\hline $\mathrm{N}_{60} \mathrm{~K}_{40}$ & 9,9 & 2,6 & 0,3 & 0,3 & 0,3 & 0,9 \\
\hline $\mathrm{N}_{90} \mathrm{~K}_{60}$ & 10,0 & 4,7 & 2,9 & 0,5 & 2,6 & 28,7 \\
\hline $\mathrm{N}_{120} \mathrm{~K}_{80}$ & 9,9 & 7,7 & 5,2 & 2,1 & 4,6 & 51,6 \\
\hline \multicolumn{7}{|c|}{ Inoculation with Diazobacteryn } \\
\hline $\begin{array}{l}\text { Without } \\
\text { fertilizers }\end{array}$ & 0,3 & 0,5 & 0,3 & 0,3 & 0,3 & 0,5 \\
\hline $\mathrm{N}_{30} \mathrm{~K}_{20}$ & 1,0 & 0,5 & 0,3 & 0,3 & 0,3 & 1,1 \\
\hline $\mathrm{N}_{60} \mathrm{~K}_{40}$ & 4,7 & 1,0 & 0,3 & 0,3 & 0,5 & 5,2 \\
\hline $\mathrm{N}_{90} \mathrm{~K}_{60}$ & 7,9 & 2,6 & 1,7 & 1,6 & 2,6 & 5,2 \\
\hline $\mathrm{N}_{120} \mathrm{~K}_{80}$ & 10,0 & 9,8 & 1,1 & 2,6 & 4,6 & 8,6 \\
\hline
\end{tabular}

Notes: * — determination on Vinogradskiy medium; ** — determination on Watson-Waterbern medium.

Table 2. Influence of seeds inoculation and mineral fertilizers on the development of nitrifying bacteria in rhizosphere soil of winter rye plants, 2012

\begin{tabular}{|c|c|c|c|c|c|c|}
\hline \multirow{3}{*}{ Variants } & \multicolumn{6}{|c|}{ Number of bacteria, tsnd. in $1 \mathrm{~g}$ dry soil } \\
\hline & \multicolumn{3}{|c|}{$\begin{array}{l}\text { Autotrophic nitrifying bacteria } \\
\text { of I phase }\end{array}$} & \multicolumn{3}{|c|}{$\begin{array}{l}\text { Autotrophic nitrifying bacteria } \\
\text { of II phase }\end{array}$} \\
\hline & $\begin{array}{c}\text { Stem } \\
\text { elongation }\end{array}$ & Flowering & Milk stage & $\begin{array}{c}\text { Stem } \\
\text { elongation }\end{array}$ & Flowering & Milk stage \\
\hline \multicolumn{7}{|c|}{ Without inoculation } \\
\hline $\begin{array}{l}\text { Without fertili- } \\
\text { zers, control }\end{array}$ & 4,8 & 7,9 & 2,1 & 2,6 & 1,0 & 0,5 \\
\hline $\mathrm{N}_{30} \mathrm{~K}_{20}$ & 4,8 & 9,9 & 2,1 & 2,7 & 1,0 & 2,6 \\
\hline $\mathrm{N}_{60} \mathrm{~K}_{40}$ & 26,7 & 9,9 & 10,1 & 2,7 & 1,0 & 2,7 \\
\hline $\mathrm{N}_{90} \mathrm{~K}_{60}$ & 26,7 & 15,6 & 26,1 & 4,8 & 2,6 & 9,9 \\
\hline $\mathrm{N}_{120} \mathrm{~K}_{80}$ & 26,2 & 20,8 & 26,0 & 4,7 & 4,7 & 9,9 \\
\hline \multicolumn{7}{|c|}{ Inoculation with Diazobacteryn } \\
\hline $\begin{array}{l}\text { Without } \\
\text { fertilizers }\end{array}$ & 8,0 & 10,0 & 1,6 & 2,7 & 1,0 & 1,0 \\
\hline $\mathrm{N}_{30} \mathrm{~K}_{20}$ & 10,1 & 12,2 & 8,50 & 2,7 & 2,7 & 1,0 \\
\hline $\mathrm{N}_{60} \mathrm{~K}_{40}$ & 10,2 & 15,8 & 48,4 & 2,7 & 2,6 & 2,7 \\
\hline $\mathrm{N}_{90} \mathrm{~K}_{60}$ & 79,1 & 15,7 & 47,8 & 10,0 & 4,7 & 2,7 \\
\hline $\mathrm{N}_{120} \mathrm{~K}_{80}$ & 78,3 & 26,1 & 100,6 & 15,7 & 9,9 & 4,8 \\
\hline
\end{tabular}

Notes: * — determination on Vinogradskiy medium; ** — determination on Watson-Waterbern medium.

the activity increase at the beginning of the growing season (tillering stage) was caused by the heterotrophic nitrification. Further contribution of heterotrophs to the formation of a pool of nitrates was insignificant and was stable during the growing season. Using the microbial preparation Diazobacteryn in the technology of winter rye growing had magnified the nitrification process during the early stages of plants organogenesis. Comparison of autotrophic and hete- 
Table 3. Influence of seeds inoculation and mineral fertilizers on the development of nitrifying bacteria in rhizosphere soil of winter rye plants, 2013

\begin{tabular}{|c|c|c|c|c|c|c|}
\hline \multirow{3}{*}{ Variants } & \multicolumn{6}{|c|}{ Number of bacteria, tsnd. in $1 \mathrm{~g}$ dry soil } \\
\hline & \multicolumn{3}{|c|}{$\begin{array}{l}\text { Autotrophic nitrifying bacteria } \\
\text { of I phase }\end{array}$} & \multicolumn{3}{|c|}{$\begin{array}{l}\text { Autotrophic nitrifying bacteria } \\
\text { of II phase }\end{array}$} \\
\hline & $\begin{array}{c}\text { Stem } \\
\text { elongation }\end{array}$ & Flowering & Milk stage & $\begin{array}{c}\text { Stem } \\
\text { elongation }\end{array}$ & Flowering & Milk stage \\
\hline \multicolumn{7}{|c|}{ Without inoculation } \\
\hline $\begin{array}{l}\text { Without fertili- } \\
\text { zers, control }\end{array}$ & 5,3 & 2,6 & 2,8 & 3,0 & 1,0 & 1,7 \\
\hline $\mathrm{N}_{30} \mathrm{~K}_{20}$ & 5,4 & 2,7 & 2,9 & 3,0 & 1,6 & 2,9 \\
\hline $\mathrm{N}_{60} \mathrm{~K}_{40}$ & 29,9 & 2,6 & 5,3 & 3,0 & 2,1 & 2,9 \\
\hline $\mathrm{N}_{90} \mathrm{~K}_{60}$ & 29,6 & 4,7 & 8,6 & 5,3 & 2,6 & 5,2 \\
\hline $\mathrm{N}_{120} \mathrm{~K}_{80}$ & 29,6 & 7,9 & 11,1 & 5,3 & 4,7 & 5,2 \\
\hline \multicolumn{7}{|c|}{ Inoculation with Diazobacteryn } \\
\hline $\begin{array}{l}\text { Without } \\
\text { fertilizers }\end{array}$ & 8,9 & 2,6 & 2,9 & 3,0 & 1,0 & 1,1 \\
\hline $\mathrm{N}_{30} \mathrm{~K}_{20}$ & 8,9 & 2,6 & 3,0 & 3,0 & 2,6 & 1,8 \\
\hline $\mathrm{N}_{60} \mathrm{~K}_{40}$ & 11,3 & 4,6 & 2,9 & 3,0 & 2,6 & 2,9 \\
\hline $\mathrm{N}_{90} \mathrm{~K}_{60}$ & 55,1 & 9,8 & 5,3 & 9,2 & 4,6 & 3,0 \\
\hline $\mathrm{N}_{120} \mathrm{~K}_{80}$ & 54,5 & 26,2 & 11,4 & 9,1 & 10,0 & 5,4 \\
\hline
\end{tabular}

Notes: * — determination on Vinogradskiy medium; ** — determination on Watson-Waterbern medium.

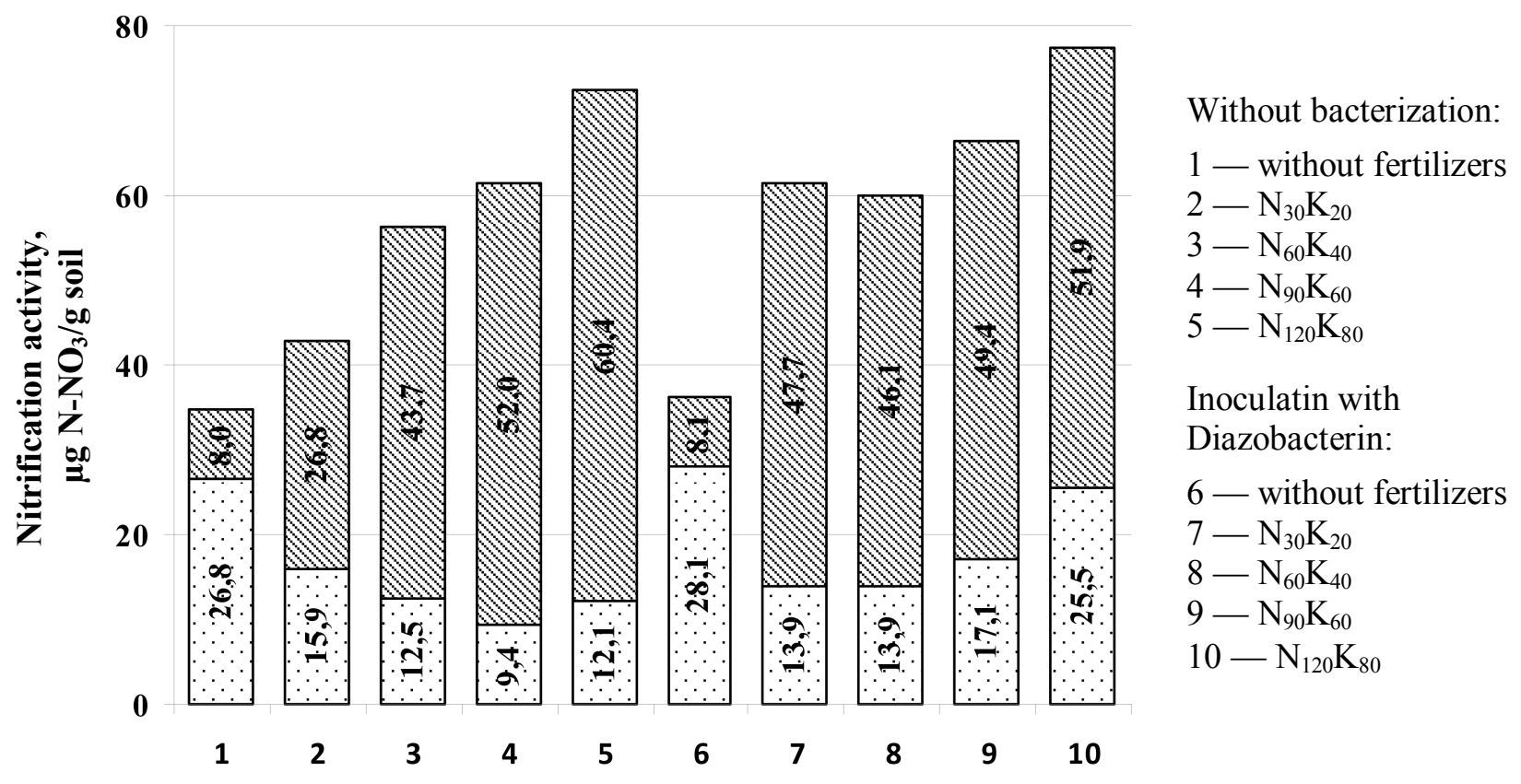

$\square$ Autotrophic nitrification $\&$ Heterotrophic nitrification

Fig. 1. Nitrification activity in rhizosphere soil of winter rye plants under the influence of mineral fertilizers and inoculation, 2013; Tillering stage (in 14 days after spring application of planned

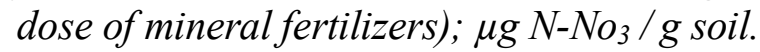

Notes: $L S D_{05}$ for total nitrification activity: for experiment - 6.07, for fertilizers - 4.29, for inoculation and interaction - 2.48; $L S D_{05}$ for autotrophic nitrification activity: for experiment - 0.82, for fertilizers - 0.58, for inoculation and interaction - 0.34; $L S D_{05}$ for heterotrophic nitrification activity: for experiment - 5.79, for fertilizers - 4.09, for inoculation and interaction - 2.36. 


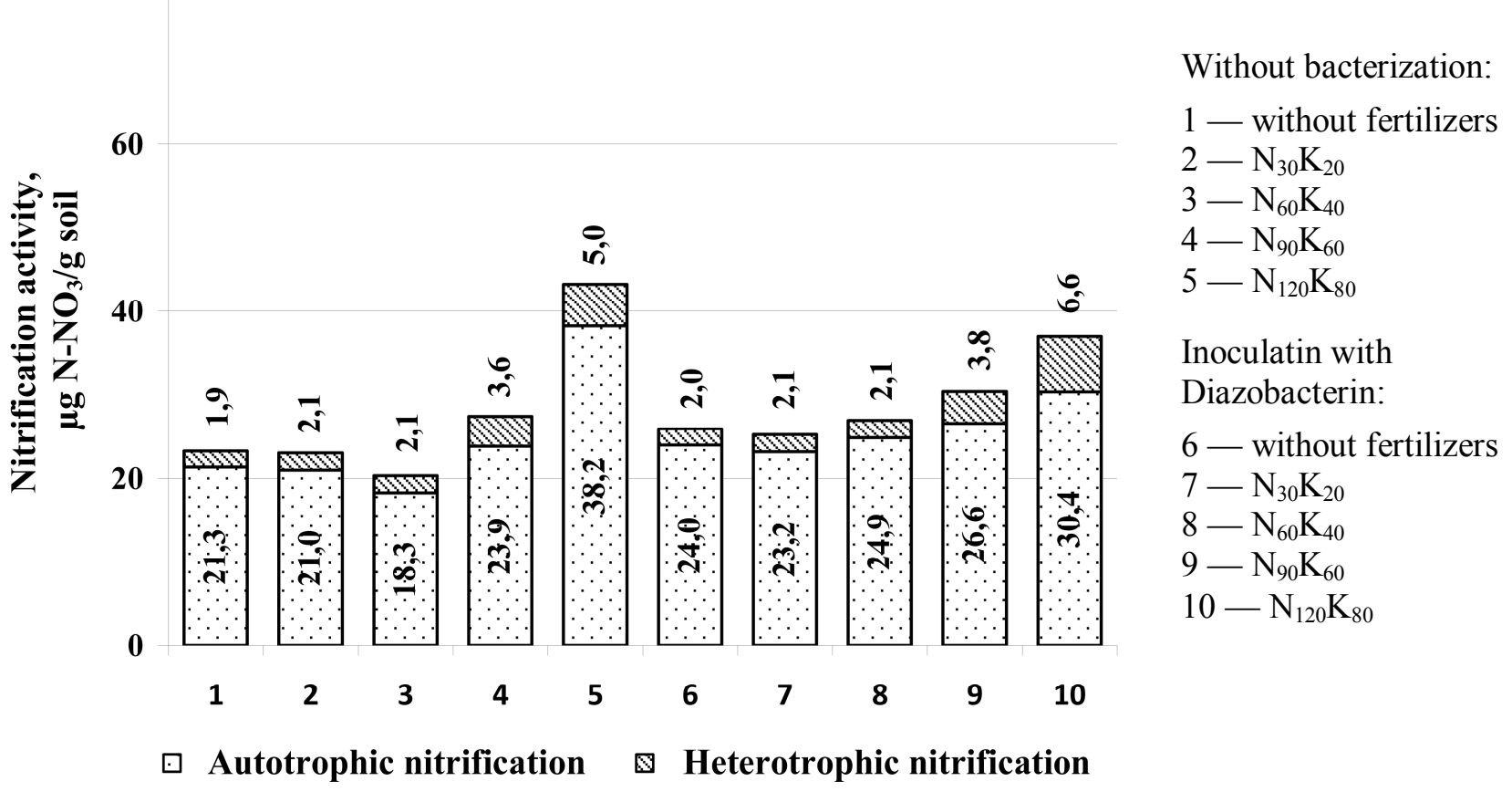

Fig. 2. Nitrification activity in rhizosphere soil of winter rye plants under the influence of mineral fertilizers and inoculation, 2013; Flowering stage (in 50 days after the early spring fertilizers application and 13 days after the plants dressing with mineral nitrogen in corresponded variants); $\mu \mathrm{g} \mathrm{N}-\mathrm{NO}_{3} / \mathrm{g}$ soil.

Notes: $L S D_{05}$ for total nitrification activity: for experiment - 3.90, for fertilizers -2.76 , for inoculation and interaction - 1.59; $L S D_{05}$ for autotrophic nitrification activity: for experiment - 0.76, for fertilizers - 0.54, for inoculation and interaction - 0.31; $L S D_{05}$ for heterotrophic nitrification activity: for experiment - 0.99, for fertilizers - 0.70, for inoculation and interaction - 0.40.

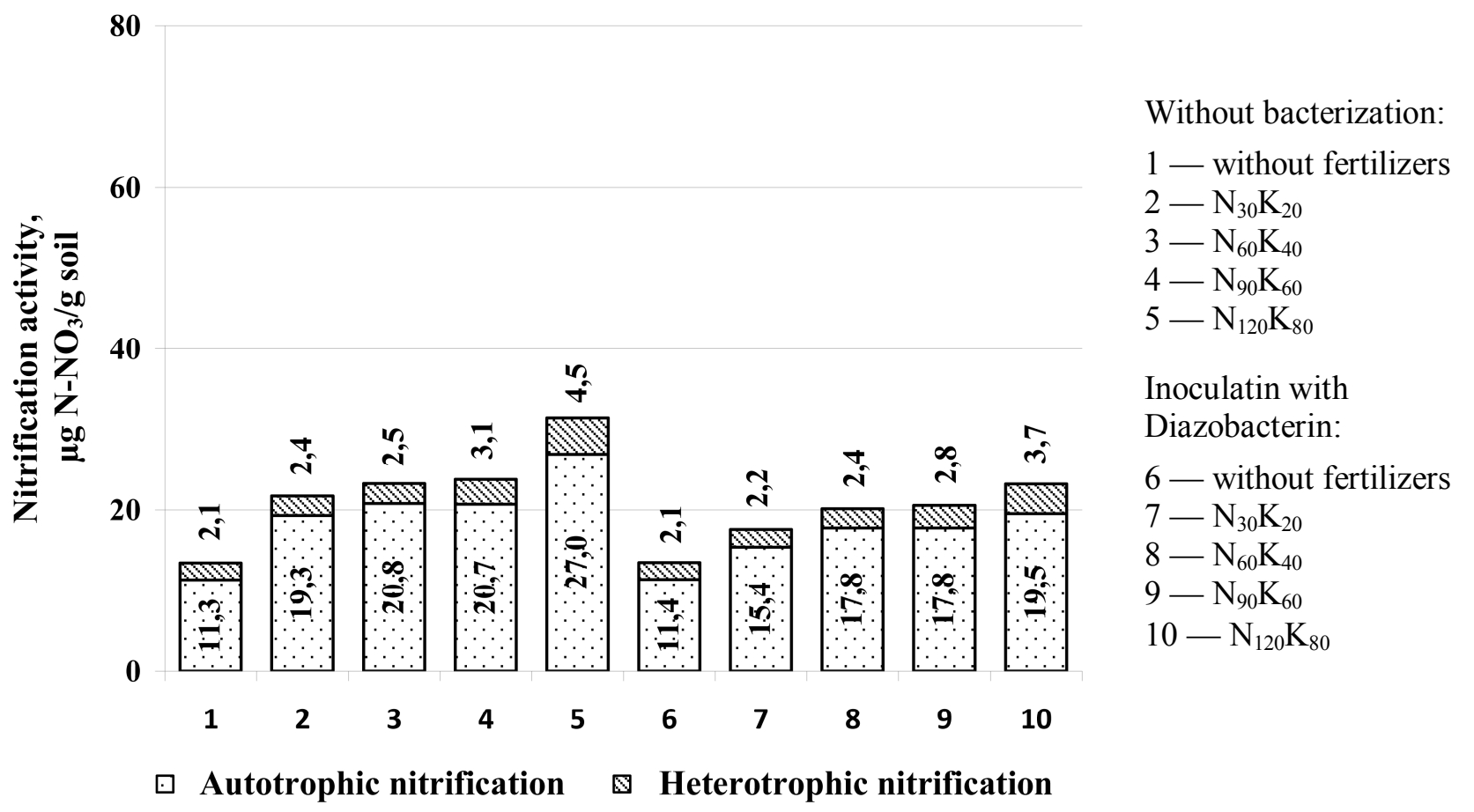

Fig. 3. Nitrification activity in rhizosphere soil of winter rye plants under the influence of mi-

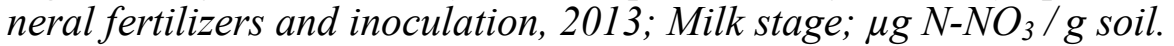

Notes: $L S D_{05}$ for total nitrification activity: for experiment - 1.62, for fertilizers - 1.14, for inoculation and interaction - 0.66; $L S D_{05}$ for autotrophic nitrification activity: for experiment - 1.97, for fertilizers -1.39 , for inoculation and interaction - 0.80; $L S D_{05}$ for heterotrophic nitrification activity: for experiment - 0.54, for fertilizers - 0.38, for inoculation and interaction - 0.22. 
rotrophic nitrification indicators had indicated that the observed increase was caused by the intensification of heterotrophic microorganisms. Later, with the development of plants, its activity in the variants with bacterization have reduced, probably due to the intense plant growth and, consequently, with a decrease of ammonium content in soil.

As for almost a century (since the discovery of autotrophic nitrification process by S. M. Vinogradskiy) it was believed that nitrification is performed only by autotrophic nitrifying bacteria of the first and second phases and only recently the existence of heterotrophic nitrification process was established. This naturally raises the question whether for a prolonged time the statement on the exclusive role of autotrophic nitrification was based on outdated methods or the whole process was studied exclusively in topsoil without taking into the account the plants role in the process of nitrogen transformation. In our studies we've tried to clarify this.

In order to exclude role of plants in the nitrification process we have determined the potential autotrophic and heterotrophic nitrification activity on fallow fields and have compared data with the one obtained from the rhizosphere soil. As noted above, plants play the main role in the intensification of nitrification process at the beginning of the growing season, providing carbon compounds to the bacteria along with the soil root exudates (Table 4). Thus in rhizosphere soil of winter rye plants the total nitrification activity was in 1.5-3 times higher comparing to the activity of the process in the fallow soil plots.

It should be noted that at the beginning of vegetation the activity of heterotrophic nitrification in the rhizosphere soil of winter rye plants was in 1.5-5 times higher comparing to the fallow soil (Table 5). The potential activity of heterotrophic nitrification in the fallow soils was 11.08-12.09 $\mu \mathrm{g} \mathrm{N}-\mathrm{NO}_{3} / \mathrm{g}$ soil, while the nitrification activity in rhizosphere soil of winter rye plants had ranged from 17.96 to $70.34 \mu \mathrm{g}$ $\mathrm{N}-\mathrm{NO}_{3} / \mathrm{g}$ soil depending upon the dose of fertilizers.

The obtained results were absolutely logical as in rhizosphere soil the number of easily accessible for heterotrophic nitrifying microorganisms organic substances is significantly higher (i. e., "rhizosphere effect" already known for other groups of microorganisms). Throughout the growing season activity heterotrophic nitrification in the rhizosphere soil of winter rye plants was also higher than in fallow soils. However, the highest indicators was observed in during the tillering stage, when the root exudation is likely the highest.

We should also note the positive impact of plants on the activity of autotrophic nitrifying bacteria, which, we assume, is related to the increase of $\mathrm{CO}_{2}$ flow to the root zone of plants because of metabolic conversion of organic compounds of root exudates.

Table 4. Total nitrification activity in rhizosphere and fallow soils, field experiment, 2013, $\mu \mathrm{g} \mathrm{N}-\mathrm{NO}_{3} / \mathrm{g}$ soil

\begin{tabular}{|c|c|c|c|}
\hline Variants & Tillering stage & Flowering stage & Milk stage \\
\hline \multicolumn{4}{|c|}{ Without fertilizers } \\
\hline Fallow soil & $82,66 \pm 5,68$ & $44,65 \pm 1,52$ & $43,01 \pm 5,69$ \\
\hline Rhizosphere soil & $302,45 \pm 9,45$ & $71,36 \pm 7,41$ & $101,20 \pm 6,74$ \\
\hline \multicolumn{4}{|c|}{$N_{30} K_{20}$} \\
\hline Fallow soil & $108,31 \pm 2,19$ & $70,06 \pm 5,77$ & $78,99 \pm 3,11$ \\
\hline Rhizosphere soil & $343,53 \pm 2,40$ & $92,08 \pm 8,82$ & $107,93 \pm 7,00$ \\
\hline \multicolumn{4}{|c|}{$N_{60} K_{40}$} \\
\hline Fallow soil & $138,35 \pm 13,09$ & $87,03 \pm 2,34$ & $92,91 \pm 1,89$ \\
\hline Rhizosphere soil & $332,12 \pm 6,39$ & $117,97 \pm 5,15$ & $118,12 \pm 8,77$ \\
\hline \multicolumn{4}{|c|}{$N_{90} K_{60}$} \\
\hline Fallow soil & $290,08 \pm 6,32$ & $214,65 \pm 20,45$ & $152,67 \pm 9,12$ \\
\hline Rhizosphere soil & $362,48 \pm 7,62$ & $293,21 \pm 27,13$ & $175,62 \pm 11,65$ \\
\hline \multicolumn{4}{|c|}{$N_{120} K_{80}$} \\
\hline Fallow soil & $297,94 \pm 10,99$ & $238,63 \pm 8,29$ & $160,09 \pm 10,60$ \\
\hline Rhizosphere soil & $389,56 \pm 6,31$ & $319,59 \pm 22,93$ & $218,56 \pm 5,98$ \\
\hline
\end{tabular}


Table 5. Activity of heterotrophic nitrification in rhizosphere and fallow soils, field experiment, 2013, $\mu \mathrm{g} \mathrm{N}-\mathrm{NO}_{3} / \mathrm{g}$ soil

\begin{tabular}{|c|c|c|c|}
\hline Variants & Tillering stage & Flowering stage & Milk stage \\
\hline \multicolumn{4}{|c|}{ Without fertilizers } \\
\hline Fallow soil & $11,80 \pm 1,14$ & $2,17 \pm 0,03$ & $1,26 \pm 0,16$ \\
\hline Rhizosphere soil & $17,96 \pm 0,59$ & $2,17 \pm 0,18$ & $2,40 \pm 0,26$ \\
\hline \multicolumn{4}{|c|}{$N_{30} K_{20}$} \\
\hline Fallow soil & $11,34 \pm 0,56$ & $2,50 \pm 0,23$ & $1,80 \pm 0,10$ \\
\hline Rhizosphere soil & $37,80 \pm 0,79$ & $2,63 \pm 0,18$ & $3,38 \pm 0,47$ \\
\hline \multicolumn{4}{|c|}{$N_{60} K_{40}$} \\
\hline Fallow soil & $12,09 \pm 0,15$ & $2,12 \pm 0,41$ & $2,08 \pm 0,03$ \\
\hline Rhizosphere soil & $54,45 \pm 0,40$ & $3,25 \pm 0,45$ & $3,84 \pm 0,34$ \\
\hline \multicolumn{4}{|c|}{$N_{90} K_{60}$} \\
\hline Fallow soil & $11,83 \pm 0,26$ & $3,56 \pm 0,21$ & $3,29 \pm 0,39$ \\
\hline Rhizosphere soil & $60,89 \pm 0,82$ & $4,71 \pm 0,47$ & $4,88 \pm 0,33$ \\
\hline \multicolumn{4}{|c|}{$N_{120} R_{80}$} \\
\hline Fallow soil & $12,06 \pm 0,17$ & $5,16 \pm 0,23$ & $5,17 \pm 0,39$ \\
\hline Rhizosphere soil & $70,34 \pm 1,10$ & $7,62 \pm 0,55$ & $7,45 \pm 0,48$ \\
\hline
\end{tabular}

Consequently, the nitrification activity in the root zone of winter rye plants rises with the increasing doses of mineral nitrogen. Heterotrophic nitrification plays a significant role in the formation of nitrate pool in the root zone of plants, especially during the early stages of plants organogenesis. Pre-sowing bacterization of winter rye seeds ensures the growth of autotrophic and heterotrophic nitrification process activity in the rhizosphere soil of plants during the early stages of their development and its reduction during the next phases of ontogenesis. In fallow soils the contribution of heterotrophic nitrification process into the biological transformation of nitrogen was negligible.

1. Кудеяров В. Н. Азотно-углеродный баланс в почве / Кудеяров В. Н. // Почвоведение. 1999. - № 1. - С. 73-82.

2. Агроекологічна оцінка мінеральних добрив та пестицидів : монографія / [В. П. Патика, Н. А. Макаренко, Л. І. Моклячук та ін.] ; за ред. В. П. Патики. - К. : Основа, 2005. - С. 93-94.

3. Умаров М. М. Микробиологическая трансформация азота в почве / М. М. Умаров, А. В. Кураков, А. Л. Степанов // М. : ГЕОС, 2007. - $138 \mathrm{c}$.

4. Кураков А. В. Нитрифицирующая актив- ность и фитотоксичность почвенных микроскопических грибов / А. В. Кураков, А. И. Попов // Почвоведение. - 1995. - № 3. - С. 314-321.

5. Нитрифицирующая активность микроскопических грибов на питательных средах и в почве / Кураков А. В., Попов А. И., Евдокимов И. В., Култышева Е. М. // Вестник Московского университета. Серия 17. Почвоведение. - 1995. T. 17, № 1. - C. 54-62.

6. Кураков А. В. Нитрификация в целинной и окультуренной темно-каштановой почве / А. В. Краков, Е. М. Култышева // Почвоведение. - 1991. - № 12. - С. 120-124.

7. Експериментальна грунтова мікробіологія : монографія / [В. В. Волкогон, О. В. Надкернична, Л. М. Токмакова та ін.] ; за наук ред. В. В. Волкогона. - К. : Аграр. наука, 2010. $464 \mathrm{c}$.

8. Методы почвенной микробиологии и биохимии : учеб. пособие / [И. В. Асеева, И. П. Бабьева, Б. А. Бызов и др.] ; под ред. Д. Г. Звягинцева. - М. : Изд-во МГУ, 1991. — 304 с.

9. Почвы. Определение нитратов ионометрическим методом. ГОСТ 26951-86. Введ. 01.07.1987. - М. : Изд-во стандартов, 1986. — $10 \mathrm{c}$.

10. Агрономическая микробиология / под ред. Г. С. Муромцева. - Л. : Колос, 1976. $231 \mathrm{c}$. 
ОСОБЛИВОСТІ ПРОЦЕСІВ

АВТОТРОФНОÏ I ГЕТЕРОТРОФНОÏ

НІТРИФІКАЦІЇ В КОРЕНЕВІЙ ЗОНІ

РОСЛИН ЖИТА ОЗИМОГО

ЗА ВПЛИВУ МІНЕРАЛЬНИХ ДОБРИВ

ТА ДІАЗОБАКТЕРИНУ

\section{І. Г. Коротка, В. В. Волкогон}

Інститут сільськогосподарської мікробіології та агропромислового виробництва НААН, м. Чернігів

Досліджено вплив мінерального азоту та передпосівної бактеризачії на розвиток нітрифікувальних мікроорганізмів та активність прочесів автотрофної $i$ гетеротрофної нітрифікаиії. Активність нітрифікації в кореневій зоні рослин жита озимого зростає при збільшенні доз мінерального азоту. Гетеротрофна нітрифікація відіграє помітну роль у формуванні нітратного пулу в кореневій зоні рослин, особливо на початкових етапах органогенезу. Застосування мікробного препарату Діазобактерину забезпечує зростання активності прочесів автотрофної $i$ гетеротрофної нітрифікаиії в ризосферному трунті рослин навесні, на перших етапах їх розвитку, $і$ зменшення - у подальші фази органогенезу. У трунті без рослин внесок гетеротрофної нітрифікаиії в процеси біологічної трансформації азоту незначний.

Ключові слова: автотрофна нітрифікаиія, гетеротрофна нітрифікачія, Діазобактерин, жито озиме, інокулячія, мінеральні добрива.

\section{ОСОБЕННОСТИ ПРОЦЕССОВ АВТО- ТРОФНОЙ И ГЕТЕРОТРОФНОЙ НИТРИФИКАЦИИ В КОРНЕВОЙ ЗОНЕ РАСТЕНИЙ ОЗИМОЙ РЖИ ПОД ВЛИЯНИЕМ МИНЕРАЛЬНЫХ УДОБРЕНИЙ И ДИАЗОБАКТЕРИНА}

\section{И. Г. Короткая, В. В. Волкогон}

Институт сельскохозяйственной микробиологии и агропромышленного производства НААН, г. Чернигов

Исследовано влияние минерального азота и предпосевной бактеризации на развитие нитрифицирующих микроорганизмов $и$ активность прочессов автотрофной и гетеротрофной нитрификачии. Активность нитрификации в корневой зоне растений ржи озимой возрастает при увеличении доз минерального азота. Гетеротрофная нитрификация играет заметную роль в формировании нитратного пула в корневой зоне растений, особенно на начальных этапах органогенеза. Применение микробного препарата Диазобактерина обеспечивает усиление активности процессов автотрофной и гетеротрофной нитрификачии в ризосферной почве растений весной, на первых этапах их развития, и уменьшение - в последуюшие фазы органогенеза. В почве без растений вклад гетеротрофной нитрификачии в прочессы биологической трансформачии азота незначителен.

Ключевые слова: автотрофная нитрификация, гетеротрофная нитрификация, Диазобактерин, рожь озимая, инокулячия, минеральные удобрения. 